ROCZNIKI HUMANISTYCZNE

Tom LXVIII, zeszyt $11-2020$

DOI: $\overline{\text { https://doi.org/10.18290/rh206811-7 }}$

MARÍA BEATRIZ HERNÁNDEZ PÉREZ

\title{
LIMINAL SPACES IN THE ANCRENE WISSE
}

\begin{abstract}
A b stract. The historical approach to the situation of female recluses who lived in small communities in the High Middle Ages has fostered the interest in the literature of formation produced at the time for such groups. While referring to the female need to remain in seclusion, one of these pieces, the early 13th-century Ancrene Wisse, also shows a profound concern over those servants who, following their ladies into their religious retirement, still belonged to the world and served as a link with the outer sphere. This work will analyze how Ancrene Wisse, while still dictating and enacting the discourse of enclosure for religious women, also permits a more lenient treatment on the issue of the presence of servants, a duality that renders the piece as a peculiar dialogic one.
\end{abstract}

Keywords: anchorhold; Ancrene Wisse; female space; Middle Ages.

\section{INTRODUCTION}

Studying the life conditions of medieval female recluses or nuns inextricably leads to further consideration of perceptions of habitation practices which may better reveal the degree of privacy and solitude these women would enjoy in their capacity to hold to their particular rooms. ${ }^{1}$ Gender studies

María Beatriz Hernández PÉrez, a tenured lecturer at the Universidad de La Laguna and a member of its Institute for Medieval and Renaissance Studies; address for correspondence: Universidad de La Laguna, Departamento de Filología Inglesa y Alemana, Campus de Guajara, San Cristóbal de La Laguna, Apto. 456, CP. 38200, Canary Islands, Spain; e-mail: bhernanp@ull.edu.es; ORCID: https://orcid.org/ 0000-0003-1739-9161.

${ }^{1}$ In medieval studies, the gender-spatial question has received due attention since the early twentieth century, especially after Eileen Power's essential contribution. The research on medieval women, especially the religious ones, has been developed by historians like Jo Ann McNamara, Roberta Gilchrist, Bruce Vernarde, or Diana Wood, while literature and cultural products have also been taken into account as evidence of this phenomenon in the works of Carolyn Walker-Bynum, Jocelyn Wogan-Browne, Julie Ann Smith, Jane T. Schulenburg, Barbara Newman, or Clare A. Lees and Gillian Overing, Carolyn Dinshaw, among many others. 
have focused on this key issue of spatial distribution in order to determine women's capacity to recreate and redefine their female condition. If, on the one hand, feminist theories have striven to prove that the patriarchal system partly rests on the control of the female body and the curtailment of female movement, it has also acknowledged the female need to create "a room of one's own." The general issue of location related to female agency and the creation of new forms of female organization has thus become a most recurrent one in gender perspective approaches. In 2001, Shari Horner's coinage of the discourse of enclosure in Anglo-Saxon culture broadened the field to the issue of the perception of sacred space as symbolic of the sacred body. As part of this medieval discourse, virginity became the quintessence of female saintliness and a condition for most religious women. Consequently, the necessity to keep to one's cell in solitude became a must in women's literature of formation. This accounts for some contents of the prose works written for the small West Midlands community of female recluses who, by the early thirteenth century, received this Ancrene Wisse and the set of hagiographies known as The Katherine Group.

\section{LOCATING RETIREMENT IN THE MIDDLE AGES: SO FAR, SO CLOSE}

Prisons or cages, literal or symbolic, are mainly defined by the sense of confinement their limits impose on those inhabiting them. However incontestable this statement, particular perceptions of constricting space are historically determined, and these may, therefore, have been sensed differently through the centuries. As Henri Lefebvre ${ }^{2}$ clearly stated when pointing out that each society creates a particular set of bonds regarding this dimension, spatial concerns comprise not only the double or triple interaction between the social relations of production and reproduction, but also their consequent symbolic layers: "Symbolic representation serves to maintain these social relations in a state of coexistence and cohesion. It displays them while displacing them, concealing them in symbolic fashion, with the help of nature" (Lefebvre 32). The Middle Ages had their own habitation structures and symbols, among which religious buildings, monasteries, abbeys or cathedrals, along with castles and walled cities served as space power referents

\footnotetext{
${ }^{2}$ This pioneer 1974 work set the path for subsequent researchers, who have delved into the study of the consequences of that spatial turn in fields such as geography, urban and cultural studies, or sociology. A remarkable survey of such new projections can be found in Robert T. Tally's work.
} 
cutting across the well-known and tilled agrarian landscape or untamed natural sceneries. But apart from these prototypical referents, the medieval experience also incorporated a more ancient residence, one directly associated to nature as an elementary form of habitat. For those withdrawing from the world due to causes such as eremitic urges or criminal persecution, caves, huts under the forest coverage, crags or deserts would become a suitable dwelling place away from social inclemency. ${ }^{3}$ In such surroundings, solitude would be the main frontier to the roaming soul; those sentenced or willingly searching for such loneliness would therefore need no architectural barriers. This ancient type of hermit and dwelling would be most cherished by audiences and readers of hagiography in the early medieval centuries. However, the early model was soon followed by one where the sense of seclusion was created not only through the practice of solitary retirement but as well by the architectural frame certifying such confinement. The imagery we today identify as medieval is the result of a codification of different kinds of compartments, and as such, can be de-codified. In this paper I will address the way some texts codify (through the regulation of physical space) that which pertains to social and gender categories.

\section{RELIGIOUS WOMEN AT THE CROSSROADS}

The Ancrene Wisse can be defined as "a beginner's guide for female recluses" (Wada 1), probably made for three daughters of a good Herefordshire family in the second quarter of the thirteenth century. The guide seems to have gained popularity very soon, since from being used by its intended audience, it moved further to other kinds of readers and followers, both religious and lay, male and female. Of its seventeen versions, nine are in English, four in French, and other further four in Latin.

The fact that these three sisters seem to come from a lay family and not a community of nuns makes us wonder whether the ancrene or anchoress posed a kind of particular figure or case to the regulations of medieval religious life, and if so, whether her practices won her a liminal space in the medieval symbolic geography. As for nunneries, "post-conquest foundations

\footnotetext{
${ }^{3}$ See Peter Brown's 1988 seminal work on sexual renunciation in late Roman and early Christian movements, as well as Joyce Salisbury's reference to these early female desert virgins.
} 
were mainly suburban, (located) either on the fringes of towns ${ }^{4}$ or further out in the surrounding fields" (Gilchirst 64). As for the issue of which religious orders would emphasize isolation, James Bond presents a diverse picture depending on the way these communities succeeded in finding and settling down in the right kinds of landscape:

Relative isolation is a marked characteristic, not just of the traditionally austere orders, but also of the Benedictine, Augustinian, and Franciscan sisters. Out of a total of 150 nunneries in England and Wales, about 125 are in more or less remote rural settings. Many were perched just above flood meadows, or on the margins of marchland, which limited their accessibility. Others achieved more extreme isolation in remote valleys, surrounded by upland moors. Choices of relatively inhospitable sites are too common to be merely a product of incompetence, ignorance, or bad luck. Some rural nunneries were sited close to villages, which provided a source of agricultural labour and craftsmen. On occasions the nuns appear to have settled on the margins of a pre-existing hamlet, but in other cases, as the Chatteris (Cambridgeshire), they occupied initially isolated sites, the nunnery then acting as a magnet for lay settlement. (Bond 54)

Their remoteness did not contradict their hospitable primordial aims, as reminded by Julie Ann Smith:

Many nunneries acted as resting places for travelling clergy and laity, as schools and retreats for lay girls and women, and as hospices for the sick and poor. They maintained relics and made them available at pilgrimage sites, and organized special festivals... The place of the nunneries and canoness houses in the political and religious landscapes of their times meant that the women were often actively involved in extramural concerns. (Smith 155-56)

Notwithstanding this, a gradual obsession with female enclosure which would be overtly demanded by the 1298 Boniface VIII's papal decree meant the loss of power previously held by many of these congregations. ${ }^{5}$ Historians have

\footnotetext{
${ }^{4}$ In fact, Carola Jäggi and Uwe Lobbedey (119) already perceive a different treatment among the Cistercians: "Whereas male Cistercians favored remote sites for their monasteries, those of Cistercian nuns are often located in the vicinity of settlements, castles, or even within cities."

${ }^{5}$ In her chapter titled "Gender relationships and circles of friendship among the mulieres sanctae," Schulenburg refers to female friendship between men and women as one of those issues which has received due attention only recently: she documents the Anglo-Saxon intense activity going on in nunneries, both in the writing of letters and in the encounters between these religious women and other brothers and sisters as sign of a social and cultural tolerance regarding female agency. However, the penitential tradition studied by Smith shows how inconvenient for the proper
} 
confirmed that after the Norman Conquest most religious women saw their prerogatives diminished and their legal and intellectual capacities restricted. Eileen Power (1922) insists on the poverty of many of the late medieval nunneries (73 out of the 138 reckoned nunneries had less and 100 pounds a year in income, and 63 of them had less than 10 members), whereas for Robertson (1990), the emphasis on control and enclosure affected not only religious women and was not strictly a religious concern: the Norman Conquest coincided with the rise of feudalism and the shift from the horizontal to the hierarchical kinship system. The set of measures designed to transform the character of marriage as a sacrament and the praxis of married life itself entailed a more careful follow-up of female movements and the curtailment of some practices: "With primogeniture the female dependence on the father figure or that of the lord was made stronger and marriage an inescapable destiny.... As for the economically less favored women, it was the dowry that posed a problem, and many fathers discouraged their daughters from getting married" (Robertson 21).

No wonder, then, that in thirteenth-century England 123 out of 198 anchorites were women who came from a variety of circumstances; only 2 of the 123 had previously been nuns (Robertson 24-25). While many of the recluses of the twelfth century were from the upper classes, in the thirteenth century most of them were from the upper and middle classes. Given the decadent state of convents in Norman England, nuns must have fought to get money and pay for their own expenses, prey to lots of anxiety that would keep them away from due asceticism. It comes as no surprise that many religious, as well as lay women, decided to retire to their own anchorholds. These would provide, in theory, the peace and privacy nunneries no longer guaranteed, and ultimately the autonomy to develop intellectually and spiritually. ${ }^{6}$ Notwithstanding this, the limit between the perception of the anchorhold as either a prison or a safe haven must have been a blurred one. In spite of the possibilities offered by anchorholds in comparison to married life or nunneries, practice would prove different from the theory, since these recluses do not seem to have ultimately been in command either of their individual abode or of their social role. Although anchoritism and monastic

running of monasteries these attachments eventually were and how intimacy of any kind was to be shunned within the same abode, according to the different rules (191).

${ }^{6}$ However, these rising figures might also tell of a more thriving society capable of responding with food and plots of land for the provision of the recluses, whereby a gradual reconciliation between Norman and Anglo-Saxon populations would be enacted (Licence 90). 
enclosure are two very different phenomena, they share a number of defining characteristics, most importantly:

Both seek to confine the female religious body, to isolate that body from society, and to protect it from invasion or penetration, whether literal or spiritual. Both practices achieve this separation spatially, of course, but also symbolically: the female religious is confined within the walls of her cell or cloister, and in addition she herself symbolizes the integritas of that space, as her virginal body remains impenetrable and sacred. (Horner 16)

The insistence on female virginity accounts for a narrowing of the female paths to retirement. If male hermits could retire as far as they wanted, solitary women, instead, were compelled to keep at some distance from town, where they were subject to supervision of the ecclesiastical authorities. By the thirteenth century, English religious women trying to emulate the spiritual quest of the desert fathers and mothers in the wilderness could, therefore, do this only from the enclosed compartment, in the anchorhold. Although Anglo-Saxon literature had allowed for the exemplary lives of women who had chosen a lonely life in the desert, like St Mary of Egypt, the emphasis on virginity in more recent hagiographies attests to the reinforcement of the discourse and the practice of enclosure.

The prospects these women brought to the community depended on their being considered dead to the world. But it was precisely this sacrificial enclosure and the spiritual power of virginity, symbolized by the anchoress and her cell or the religious building, what attracted followers of all kinds. Ironically, in spite of these women's desire or duty to reject the world and keep to their sanctuary as if dead, people would keep on visiting them in order to address issues of confession, or simply to ask them to pray and intercede on their behalf (Licence 108). Thus, retirement into the anchorhold would not guarantee the displacement of these women away from the body or eye of society, but their integration into this body, instead: their literal confinement would paradoxically widen the spiritual dimension of those approaching them. As Cannon puts it: "The constant pressure of such contradictory circumstances and demands was not, however, grounds for enclosure's failure, but the material of its success" (Cannon 110). Echoing the distant voices of the saintly desert figures, these peculiar inmates would thus be actively serving the needs of the Church and would consider themselves as servants of Christ and the faithful.

As well known, The Ancrene Wisse is divided into two large groups, the so called Inner and Outer Rules. Whereas the latter is shorter and dedicated 
to regulate habits, activities and physical space, in the former the author tells of seven distinctions the young recluses should observe in order to lead a life of proper spiritual seclusion, namely: devotions, awareness of the need to control the five senses, to follow proper behavior and eschew the seven deadly sins and spiritual temptations; plus the sections devoted to confession, penance and suffering, and finally the chapter dedicated to love and the importance of having a pure heart. It is worth noting that the text does not seek an explicit affiliation to any of the standing coetaneous religious rules and is much more descriptive than prescriptive. This particular author seems opposed to the Benedictine legacy and the idea that man-made rules might stand over inner individual spiritual craving (Georgianna 29): seemingly tired of controversies over the right rule to follow and possibly quite conscious of the possibility of criticism regarding his peculiar set of rules, he even dares to joke and tells the young recluses that, when asked about theirs, they might just as well reply they are following St James', ${ }^{7}$ mentioning, however, the figure of the first hermits who had precisely retired to the desert, away from the world, as models to follow: "Pawel pe earste ancre. antoníe ant arsenie. Makarie and te opre neren ha religiuse ant of sein iames ordre? Alswa seinte Sare ant seinte Sicleclice. ant monie opre swucc hewepmen ba ant wummen, wið hare greate matten ant hare hearde héren neren ha of god ordre" ${ }^{8}$ (Tolkien 10, ls. 5-7).

However lenient at first sight, this author did underline the potential danger the wrong management of space could mean to the young addressees of his treatise, as well as the sepulchral character of their dwelling: when the anchorhold was no more than a room or rooms attached to a church in the city, after being brought there in a coffin, these women were bricked into the room and the service for the dead was said over their door. ${ }^{9}$ Accordingly, the

\footnotetext{
${ }^{7}$ When quoting from the Ancrene Wisse, I will include the page and lines in J. R. R. Tolkien's 1962 edition of the Corpus Christi College Cambridge manuscript (CCCC 402), whereas the translated quotes in footnotes will be those in Bella Millett's 2009 work, which follows the same manuscript. I will transcribe abbreviations to help readability.

8 "Paul, the First Hermit, Anthony and Arsenius, Macharius and the others, weren't they religious and of St James's order? Likewise St Sarah and St Syncletica, and many others like them, both men and women, with their coarse mats and their harsh hair-shirts; didn't they belong to a good order?" (Millett 4).

${ }^{9}$ The patristic tradition regarding virginity had realized the paradoxical nature of this condition, which conveyed its own denial in order to keep existing. This would entail covering or effacing any female features which would attract the gaze to these virgins: "In fact, a certain inescapable logic of virginity, most evident in medieval hagiography, leads syllogistically to the conclusion that the only real virgin — that is, the only true virgin — is a dead virgin" (Bloch 108). See Liz Herbert McAvoy
} 
Ancrene Wisse author keeps encouraging recluses to dig in their own grave in their cell, an option which, somehow, would discourage them from the possibility of becoming open-space hermits: "Ha schulden shcrapien euche dei pe eorðe up of hare put pet ha schulien rotien in. Godd hit wat pet put deð muche god moni ancre" ${ }^{\prime 10}$ (Tolkien 62, 1s. 23-25).

\section{SERVING AND LEARNING AT AN ANCHORHOLD}

Sometimes, though, namely in the case of some women coming from noble or middle-class families, their cell could become much more than a bare grave. Anchoresses could share a group of chambers, including their own bedrooms and those of the servants; some even had gardens. In order to benefit from the attraction exerted by them over those living in nearby areas, the Church would compensate its disallowance of female uncontrolled errand by acquiescing with a retirement with some degree of lavishness. Thus, not only the location of the anchorholds was to be made accessible to pilgrims or pious members of the community, but the sacred women could be approached through the physical intercession of their servants. In bringing these along to the anchorhold when withdrawing from the world, anchoresses somehow retained some of their former capacities. Maidservants were supposed to accompany them at all times, one of them-normally older — standing by the house window and acting on behalf of any callers or visits, while a younger one would run errands and provide any extra services the recluses required.

It is the lack of clear boundaries in the perception of enclosed space that allows the author of Ancrene Wisse to bring in naturally the outer world within his rule, one of the qualities of this prose work. Quite aware of potential peril, he lists every activity in which the recluses might be tempted to forget their estate or allow themselves some relaxation in the control of room or body. Servants being so important in the Outer Rule is not only a direct reflection of a reality, but as well an authorial decision. The author's social awareness is made evident when describing the dual nature of his rule and stating that the Inner Rule, the crucial one that should govern his readers' hearts, must be understood as a lady, whereas the Outer rule, which codifies

and Marc Hughes-Edwards for the relationship between enclosure and the functions related to burial rituals and care for the dead.

10 "They should scrape up earth every day from the grave in which they will rot. Certainly that grave does a great deal of good to many anchoresses" (Millett 46). 
issues concerning, not the heart, but the body of the recluses and their connection to the world, should be read as a handmaid to that lady, important in as much as it helps develop the Inner Rule: "ant peos riwle nis nawt bute forte serui pe oper. pe oper is as leafdi. peos as hire puften. for al pet me eauer deð of pe oper wið uten nis bute forte riwlin pe heorte widðínnen"

The dichotomy between ladies and servants is to be projected on the author's effort to present his rule properly (Grayson 222): "The advice that the author passes on to the anchoress concerning treatment of her servants may apply to the relation of author and anchoress as well. If any sins through negligence of the other, who will be called to account on Judgment Day?" The analogy runs further when the author describes the structure and features in the abode as responding to these women's habits and needs: doors having been walled, each cell used to have two or three windows covered by pieces of cloth to avoid visual contact: one through which the recluse would listen to the mass; the parlour window through which she would use the intercession of the maid to participate in conversations, and possibly, though not clear, another small one leading to the street, to an orchard or garden, or to the rest of the house. One of the maids not only informs the recluse and bears her messages to visitors, acting as her mouth and ears, but she is also given the capacity to entertain guests who come to dinner, as the anchoress is not allowed to join them. Thus, we may certainly say that this maid somehow embodies the worldly or social persona of her lady when necessary: "zet oðre religiuse as ze witen doð hit ze ahen ouer alle. zef ei haueð deore geast do hire meidnes as in hire stude to gleadien hire feire"12 (Tolkien 37, 1s. 24-26).

If the anchorhold option was a liminal one when compared to that of the nunnery, the element of maids added a surplus of instability and precariousness to the anchoretic choice. The author is quite aware of the delicate situation for these young women and reminds that, along with their servants, they should be kept to their tiny space: therefore, recluses are asked to control not only their own bodies and movements, but those of their maids as well: these are not to talk to strangers, depart from the anchorhold without notice or female company, and mainly, they are never to bring news and idle talk to the cell: "Nowðer of pe wummen ne beore from hare dame, ne ne bringe to hire,

\footnotetext{
11 "And this rule only exists to serve the other. The other is like the lady, this one like her maid; because whatever is done according to the outer rule is done only to regulate the heart internally" (Millett 1-2).

12 "If anyone has a valued guest, she should see that her maids, as it were in her place, entertain her well" (Millett 29).
} 
nane idele talen, ne neowe tidings. ne bitweonen ham seolf, ne singen ne ne speoken nane wordliche spechen. ne lahhen swa ne pleien, pet ei mon pet hit sehe, mahte hit to uuel turnen. Ouer alle pinges leasunges ant luðere wordes heatien"13 (Tolkien 218, 1s. 12-17). This concern with gossip shows how fragile the margins between the public and the private, and how exposed to common talk the anchoresses lives were. Contemporary religious authors followed an age-old tradition regarding the incorrect use of language carried out by women. Just some decades before the composition of Ancrene Wisse, the Cistercian Aelred of Rievaul $\mathrm{x}^{14}$ had warned his sister, also turned an anchoress, about the danger these old servants posed to proper asceticism (Webb 80). Karma Lochrie's thorough study of the uses of secrecy in the Middle Ages reminds that gossip was clearly associated to gender and cultural difference (Covert Operations 56-57):

Gossiping was considered in the Middle Ages to be a vice ... usually associated with women, particularly their loquaciousness, bodiliness, secrecy, and their susceptibility to deception. Gossip was also associated with a kind of insurrectionary discourse on the part of women as a marginal medieval community, one that existed alongside - but also in resistance to- a variety of institutionalized, written discourses. As such, it would be felt as threatening and liable to be subjected by male control, increasingly sensitive to the discursive capacities of female groups.

But equally interesting, gossip does not characterize women's talk exclusively, since it is one of the strategies subordinated groups of all kinds or individuals develop in order to furnish themselves with a sense of solidarity and self-expression (Spack 30). Therefore, the outstanding importance given to gossip in the Ancrene Wisse points to the male clerical anxiety either with gender considerations or with the social and economic agency of these lesser women, whose interests and perspectives might distract their ladies away from the religious higher call. That is why the author tries to teach the young recluses how to deal with their servants, by both exerting their authority when necessary but also offering their love and care. It is worth noting the passages where the author reminds the young recluses of the need to remain humble

13 "Neither of the women should carry from their mistress, or bring to her, any frivolous gossip or the latest news, or sing or recite secular material to each other, or laugh and play about in such a way that anyone who saw it might misconstrue it. Above all, they should hate lies and malicious talk" (Millett 162).

${ }^{14}$ De vita eremitica ad sororem liber, a work the Ancrene Wisse author was familiarized with. In this treatise, also referred to as De institutione inclusarum, Aelred presents gossip as the first step into further temptation and degradation of the recluse (Lochrie, Between women 72). 
(Dobson 3), even when exposed to the pride of maids: "ant beon bliðe iheortet. zef ze polieð danger of sluri pe cokes cneaue, pe wescheð ant wipeð disches I chuchene" (Tolkien 193, 1s. 2-4), and "Ase forð as ze mahen, of mete ant of claðes. ant of opre pinges pet neode of flesch easkeð, beoð large toward ham. pat ze nearowe beon ant hearde to ow seoluen"15 (Tolkien 221, 1s. 4-6).

He makes it clear that these maids should not expect any regular wages, a commentary that makes us wonder whether servants' gossip might arise for economic reasons sometimes: "Nam ancre seruant ne ahte bi riht to easkin iset hure. bute mete ant clað hure pet ha mei flutte bi, ant Godes milce. Ne mis leue nan godd, hwet se tide of pe ancre. pet he hire trukie. pe meidnes wið uten, zef ha seruið pe ancre alswa as ha ahen, hare hure schal beon pe hehe blisse of heouene"16 (Tolkien 220, 1s. 8-13). The reference to the anchoresses' sisters' maidservants paying visits through the window is most revealing of how gossip could spread into the spaces linking the separate cells:

Hwen ower sustres meidnes cumeð to ow to froure, cumeð to ham to pe purl, earunder ant ouerunder. eanes oðer twien. ant gað azein sone, to ower note gastelich. ne biuore Complie ne sitte ze nawt for ham ouer riht tíme. swa pet hare cume beo na lure of ower religion, ah gastelich bizete. zef per is eani word iseid ant mahte hurten heorte, ne beo hit nawt iboren ut, ne ibroht to oper ancre, ant is eð hurte. To him hit schal beon ised, pe lokeð ham alle. ${ }^{17}$ (Tolkien 221 , ls. 11-19)

Certainly, gender, social, and economic considerations intertwine and reflect the author's apprehensions: on the one hand, that of a female alternative discourse based on gossip which might trespass the ecclesiastical frame and walls given to anchoresses. On the other hand, that against the glimpse of social awareness arising in the young girls through contact and identification

15 "and be glad if you have to put up with the insolence of Slurry the cook's boy, who washes and wipes dishes in the kitchen" (Millett 143); "As far as you can, be generous towards them with food and clothes and other things which their bodily needs require, even if you are sparing and hard on yourselves" (Millett 164).

16 "It is not proper that any recluse's servant should ask for a fixed wage, apart from food and clothing enough for her to manage on, and the mercy of God. Nor should any servant fear be afraid that God will let her down, whatever may happen to the anchoress. If her external maids serve the anchoress as they are supposed to, their reward will be the exalted bliss of heaven" (Millett 163).

17 "When your sisters' maids pay you a visit, come to them at the window in the morning and afternoon once or twice, and go straight back to your spiritual duties, and do not sit too long before Compline on their account, so that their visit may not mean the loss of any of your spiritual observances, but spiritual gain. If anything is said that might cause hurt feelings, it should not be repeated outside or told to another anchoress who is easily hurt. It should be told to the man who supervises them all" (Millett 164). 
with their servants. The former has to do with the basic similarities between gossip and confession, since both forms of utterance share an oral aspect and the element of secrecy: compulsory confession is precisely one of the thirteenth-century Church key contributions to medieval and modern spiritual life, and the prerogative of male ecclesiastics. But anchoresses might somehow transgress those limits when being visited by people wondering about their sins and the proper way to talk to priests about them. If consultation and informal confession went about through the thin curtain of the parlor window and the servant woman could remain at her due post meanwhile, either by the house or the parlor windows, we can understand the double anxiety of priests and bishops concerning the revelation and circulation of news from cell to town and vice versa. Thus, their emphasis on supervising the whole process, as perceived in the text:

Wið uten witnesse of wummon oðer of wepmon pe ow mahe iheren ne speoke ze wið namon ofte ne longe. ant tah hit beo of schrift, allegate I pe ilke hus. Oðer per he mahe iseon toward ow sitte pe pridde. Bute zef pe ilke prid de oper stude trukie. Pis nis nawt for ow leoue sustren iseid, ne for opre swucche. Nawt for pi pe treowe is ofte mistrowet. ant te saclese bilohen. As iosep I Genesy. Of pe gale leafdi for wone of witnesse. Me leueð pe uuele sone. ant te unwreaste bliðeliche liheð o pe gode. ${ }^{18}$ (Tolkien 37, ls. 2-12)

The reading and sharing of the rule by each of these ladies and their respective servants seems to be the only solution to fight such female misbehavior:

ze ancres ahen pis leaste stucche. me nawt blisse. Redden to ower wummen euche wike eanes. Apet ha hit cunnen. And muche neaod is bet ze neomen to ham muche zeme. For ze mahen much beon purh ham igodet. Ant iwurset. On oðer half (zef) bet ha sungið burh ower zemeles, ze schule beo bicleopet prof biuore be hehe deme. Ant for pi as ow is muche neod. And ham zet mare, zeornliche leareð ham to haldenhare riwle. Ba for ow ant for ham seolf, liðeliche atn luueliche. For swuch ah wummone lare to beonne. Luuelich ant liðe. ant selthwenne sturne. ${ }^{19}$ (Tolkien 220, 1s. 16-25)

\footnotetext{
18 "Unless you have a witness, a woman or a man who can hear you, do not talk with any man often or for a long time; and even if it is for confession, the third person should still sit in the same house, or where he can see you both, unless there is no room for a third. This is not mentioned on your account, dear sisters, or for others like you; nevertheless, the virtuous are often suspected, and the innocent slandered, as Joseph was in Genesis by the lustful lady, for lack of a witness. Malicious people are easily believed, and the wicked rejoice in slandering the good" (Millett 28).

19 "You anchoresses should read this last subsection to your women once a week until they are familiar with it. And it is most important that you take great care with them, as you can be greatly helped by them-and harmed too. What is more, if they sin through your neglect, you
} 


\section{CONCLUSION}

By suggesting the communal reading, the author is somehow acknowledging that servants are not altogether to be blamed for the hearsay activity going on around the cell: anchoresses, priests and bishops, relatives and the whole community are ingrained in the same dynamics. The surveillance of priests and bishops and their positive verdict about the recluses did, in fact, mean that these women would be further exposed to visits of followers and curious people, thus endlessly feeding gossip and reinforcing, paradoxically, the need for the discourse of enclosure. In this helplessness, it was the recluses' ultimate responsibility to extend their efforts to the training of those servants who could stand either as hurdles or as walking sticks on their spiritual progress. Sharing the ultimate aim of this last section of the treatise through the habit of reading aloud would abate the effect of gossip and add to the fortification of their spiritual landscape. D. H. Green (15-23) presents different cases where the verb legere is used to refer to reading aloud to another person or to a congregation; similarly, in many of the medieval female types recorded by Lara Farina (145-47), examples attest to how this practice would enable or strengthen intimacy among readers and listeners. If such is the case, the Ancrene Wisse author would be encouraging the intersection of social frontiers between the recluses and their servants, while still intent of making them aware of the need to keep such distances. ${ }^{20}$ Thus, the reading habit and the message conveyed by the rules would provoke or contain contradictory results and make this space of the anchorhold one where women of different social and intellectual provenance had to adjust and develop their own personal ways.

will be called to account for it before the high Judge. And as this is very important for you, and still more for them, do your best to teach them kindly and lovingly to keep their Rule, both for your sake and theirs - because that is what women's teaching should be like, loving and kindly and seldom stern" (Millett 163-64).

${ }^{20}$ In recommending that the teaching process be carried out through love rather than strict discipline, this author acknowledges the liminal position female anchorites occupied: the relationship with those beneath should not be based on stern measures leaning on the concept of distance, but mainly on love and the renewed functions of their female spaces. 


\section{WORKS CITED}

Aelred of Rievaulx. Aelredi Rievallensis. Opera omnia I: Opera Ascetica, edited by Anselm Hoste and C. H. Talbot, Brepols, 1971.

Bloch, Howard. Medieval Misogyny and the Invention of Romantic Love. U of Chicago P, 1991.

Bond, James. "English medieval nunneries: Buildings, precincts, and estates." Women and Religion in Medieval England, edited by Diana Wood, Oxbow Books, 2003, pp. 46-90.

Brown, Peter. The Body and Society. Men, Women, and Sexual Renunciation in Early Christianity. Columbia UP, 1988.

Bynum, Caroline Walker. Holy Feast and Holy Fast: The Religious Significance of Food to Medieval Women. U of California P, 1987.

Cannon, Christopher. "Enclosure." The Cambridge Companion to Medieval Women's Writing, edited by Carolyn and David Wallace, 2003, pp. 109-23.

Dinshaw, Carolyn, and David Wallace, editors. The Cambridge Companion to Medieval Women's Writing. Cambridge UP, 2003.

Dobson, E. J. The Origins of Ancrene Wisse. EETS, 1976.

Farina, Lara. "Women and Reading." The History of British Women's Wtiting, 700-1500, edited by Liz Herbert McAvoy and Diane Watt, Palgrave, 2003, pp. 142-50.

Georgianna, Lynda. The Solitary Self. Individuality in the Ancrene Wisse. Harvard UP, 1981.

Gilchrist, Roberta. Gender and Material Culture: The Archaeology of Religious Women. Routledge, 1994.

Grayson, Janet. Structure and Imagery in Ancrene Wisse. U of New Hampshire, 1974.

Green, D. H. Women Readers in the Middle Ages. Cambridge UP, 2007.

Hanawalt, Barbara, and M. Kobialka, editors. Medieval Practices of Space. U of Minnesota P, 2000.

Herbert McAvoy, Liz, and Marc Hughes-Edwards, editors. Anchorites, Wombs and Tombs. Intersections of Gender and Enclosure in the Middle Ages. U of Wales P, 2005.

Herbert McAvoy, Liz, and Diane Watt, editors. The History of British Women's Writing, 700-1500. Palgrave, 2003

Horner, Shari. The Discourse of Enclosure. State U of New York P, 2001.

Jäggi, Carola, and Uwe Lobbedey. "Church and Cloister: The Architecture of Female Monasticism in the Middle Ages." Crown \& Veil: Female Monasticism from the Fifth to the Fifteenth Centuries, edited by Jeffrey F. Hamburger and Susan Marti, Columbia UP, 2008, 109-31.

Lees, Clare A., and Gillian R. Overing. Double Agents: Women and Clerical Culture in AngloSaxon England. U of Pennsylvania P, 2001.

Lefebvre, Henri. The Production of Space. Translated by Donald Nicholson-Smith, Blackwell, 1991.

Licence, Tom. Hermits and Recluses in English Society. 950-1200. Oxford UP, 2011.

Lochrie, Karma. Covert Operations. The Medieval Uses of Secrecy. U of Pennsylvania P, 1999.

Lochrie, Karma. "Between women." The Cambridge Companion to Medieval Women's Writing, edited by Carolyn Dinshaw and David Wallace, Cambridge UP, 2003, pp. 70-90.

McNamara, Jo Ann. A New Song: Celibate Women in the First Three Christian Centuries. Harrington Park Press, 1983.

Lochrie, Karma. Sisters in Arms. Catholic Nuns through Two Millennia. Harvard UP, 1996. 
Millett, Bella. Ancrene Wisse. Guide for Anchoresses: A Translation. U of Exeter P, 2009.

Newman, Barbara. From Virile Woman to Woman Christ: Studies in Medieval Religion and Literature. U of Pennsylvania P, 1995.

Power, Eileen. Medieval English Nunneries. Cambridge UP, 1922.

Robertson, Elizabeth. Early English Devotional Prose and the Female Audience. The U of Tennessee P, 1990.

Salisbury, Joyce. Church Fathers, Independent Virgins. Verso, 1991.

Schulenburg, Jane Tibbetts. Forgetful of Their Sex: Female Sanctity and Society, ca. 500-1100. The U of Chicago P, 1998.

Smith, Julie Ann. Ordering Women's Lives: Penitentials and Nunnery Rules in the Early Medieval West. Ashgate, 2001.

Spacks, Patricia Meyer. Gossip. U of Chicago P, 1985.

Tally, Robert T. Spatiality. Routledge, 2013.

Tolkien, J. R. R. The English Text of the Ancrene Riwle: Ancrene Wisse: Edited from MS Corpus Christi College Cambridge 402. EETS, Oxford UP, 1962.

Venarde, Bruce L. Women's Monasticism and Medieval Society. Nunneries in France and England, 890-1215. Cornell UP, 1997.

Wada, Yoko. A Companion to the Ancrene Wisse. D. S. Brewer, 2003.

Webb, Diana. Privacy and Solitude in the Middle Ages. Humbledon Continuum, 2007.

Wogan-Browne, Jocelyn. Saints's Lives \& Women's Literary Culture. Virginity and Its Authorizations. Oxford UP, 2001.

Wood, Diana. Women and Religion in Medieval England. Oxbow Books, 2003.

\section{PRZESTRZENIE GRANICZNE W THE ANCRENE WISSE}

Streszczenie

Historyczne studia nad kobietami żyjącymi w małych, odizolowanych wspólnotach w czasach pełnego średniowiecza wzbudziły zainteresowanie literaturą formacyjną powstałą w tym okresie. Trzynastowieczny tekst Ancrene Wisse, opisując kobiecą potrzebę odosobnienia, jednocześnie poświęca dużo uwagi służącym, które towarzyszyły swoim paniom w ich religijnej izolacji, pozostając ogniwem łączącym je ze światem zewnętrznym. Niniejszy esej omawia sposób, w jaki Ancrene Wisse, ustanawiając reguły izolacji religijnych kobiet, jednocześnie wykazuje dużą wyrozumiałość względem obecności służby. Ta dwoistość czyni z niego osobliwy tekst dialogiczny.

Słowa kluczowe: anchorhold; Ancrene Wisse; kobieca przestrzeń; średniowiecze. 